\title{
The Politicisation of Arab Theatre: Sa'd Allah Wannus
}

\author{
Abdulaziz H. Al-Abdullah \\ University of Kuwait, Keifan, Kuwait
}

\begin{abstract}
The political theatre in the Arab world emerged from rough seas of opposition and state monitoring schemes. Some critics may claim that political tendencies in Arab theatre can be traced to the early contributors to Arab theatre. Others attribute the emergence of this theatre to the revolution of Egypt's Nasir. However, the Syrian playwright Sa'd Allah Wannus may be viewed as the true representative of this kind of theatre in the Arab world. Shocked by the defeat of the Arabs by Israel in 1967, he began what he coined “theatre of politicization”, aiming to attack Arab governments and blaming them for the defeat, and at the same time, insighting his audience to revolt against existing political ideas. In this kind of theatre, the audience assumed ever-increasing importance. Wannus wrote several plays, the aim of which was to develop a mentality and strengthen a collective consciousness in an Arab historical context. This article aims to exploring the concept of theatre of politicization and the impact of that on Arab political theatre.
\end{abstract}

Keywords: politics, theatre, insighting, frustration and dissappointment

\section{Introduction}

The 19th century marked the birth of modern Arab theatre and the beginning of a period of interplay between Arab drama and Western drama. Many studies recognize the Bilad al-Sham (Greater Syria) as where the modern Arab theatre began its life in the mid-19th century. Many great writers in all the major genres of Arabic literature have emerged from that part of the Arab world, including such figures as Marun al-Naqqash, Ahmed Aby Khalil al-Qabbani, Mikhail Nuayma, Khlil Mutran, Jibran Khalil Jibran, and many others. Each one has left his own distinctive mark on his field of literature. Such theatre was mainly an imitation of the Western form and works. Politics were not part of any play, as it is hazardous to involve everyday politics on stage, except in the form of allegory.

\section{Wannus and Political Theatre}

Political theatre arrived late in the Arab world, because personal freedom and the attainment of political maturity had been for a long time inhibited. Such a theatre is closely linked with historical events: the domination of colonisation by Western nations, especially England and France; the emergence of Israel as an independent state in 1948, with the resulting series of wars and "internal protests" against corruption and oppression. The last movement led naturally towards the spread of socialist or Marxist ideas and the concept of the universality of revolution.

Abdulaziz H. Al-Abdullah, Ph.D., Department of English, University of Kuwait. 
When the Free Officers, including Jamal Abd al-Nasir, assumed power in Egypt in 1952, the theatre in that country became much more lively and even subversive in response to the new political climate. The Syrian playwright Sa'd Allah Wannus, like most Arab people, was deeply influenced by Abd al-Nasir and his ideas on Arab unity and Pan-Arabism. However, the real emergence of the political theatre in the Arab world was to come after the humiliating defeat of June 1967, as Arab intellectuals vied with each other to find an explanation or reason for the disaster. Three trends can be detected amongst these intellectuals: (1) the liberal secular trend which attributed the defeat to the connection between religion and politics, and saw the total separation of these two elements as the right response to it; (2) the Islamic religious trend which found the cause in the abandonment by the Arabs of their religion and called for a return to religion and the enactment of Islamic legislation; and (3) the revolutionary trend which blamed corrupt governmental changes in the Arab world. Thess trends consisted mainly of Marxist and Socialist thinkers.

\section{Social Background and Early Works}

Such demands are understandable for, undoubtedly, the gap between rulers and the ruled in the Arab world had been getting wider. People had been denied the right of participation in political decision-making: They were restrained both by the actions of the opportunistic bureaucracy and by the ignorance in which they were deliberately kept by their governments. In this atmosphere, if the theatre could find a voice it needed, in the words of Mustafa al Hallaj, a Syrian playwright, quoted by A. Al-'Shari: "to move with the cycle of life and the battle of history, to become a platform for 'making' demands and a starting point for revolutionary work” (Al-'Ishari, 1985, p. 106).

A new phase began in Arab theatre as it tried to break down artificial barriers and openly examine political questions. To avoid the threat of bans or prosecution, it was often necessary for writers to use allegory: legends, symbolism, Arab history, and literary heritage. This was done by Sa'd Allah Wannus in his controversial play Haflat Samar min Ajl Khamsa Huzayran (An Evening Entertainment for the 5th of June, 1968). In this and similar plays, a dialogue was established between the audience and the playwright, actors, and directors. The theatre sought to put on trial the regimes and leaders who were seen as the reason for the catastrophic defeat.

Many playwrights in different Arab countries played a part in this movement for revival of the theatre, but Wannus has claimed to be considered the leader. After the war of 1967 and the turbulent events he had personally witnessed in 1968 in Paris, politics became the dominant factor of his life. He wrote: "I realise that the fundamental aim of the human being is to be a politician” (Wannus, 1977, p. 193). He argued that the traditional theatre, even when it avoided specifically political issues still served a political objective, that is to prevent the masses from improving or changing their conditions (Wannus, 1970, pp. 17-23). This reflected the ideas of the American theatre director Peter Schumann, and of Erwin Piscator. Wannus sought to make the theatre a didactic and stimulating experience for the masses: It should present their problems, analyze the issues affecting them, enlighten people about matters the ruling elite kept hidden factors, and encourage them to strive for change (Ramadn, 1984, p. 28). This so-called "theatre of politicisation" had to be relevant to the contemporary political situation and accessible to the masses whose cause it would champion. 


\section{The Concept of Wannus’ Theatre}

In Wannus's concept of this theatre, the audience assumed ever increasing importance. He described the theatre of politicisation as a "dialogue between two spaces - the theatrical performance, which is presented by a group aiming to establish a better form of communication with the audience, and the audience itself, in whose lives all the manifestations and problems of reality appear" (Wannus, 1987, p. 426). In the introduction to his play Haflat Samar (1977), he wrote:

In a period of set-back, when the people have only two choices-armed resistance or surrender-the task of the theatre is difficult but clear. It must break with its roots and transform the stage and the auditorium into a conscious awakening process, that must penetrate into the most distant halls of the theatre, into the streets and houses, into the front line, evolving as it spreads into protest, resistance and a clear vision of the future. The theatre betrays the people if it hides the truth. (Wannus, 1977, p. 2)

Wannus (1970) explained how he came to develop the concept of "theatre of politicisation" by saying that "the 1967 war was very important for the theatre and for its relation to politics, because the theatre, like the Arab masses, had been shocked by the defeat” (p. 106). Before the defeat, it was felt that theatrical experiments had been inhibited by the ethos of "art for art's sake". Traditional critics saw the theatre as a pure form of art which should not meddle in politics, for that could only weaken its artistic nature. But the shock of defeat created an intellectual awakening within the educated classes and led to universal agreement that the theatre could not turn its back on politics.

\section{Wannus and the Function of Theatre}

In Wannus' eyes, the theatre should carry progressive political content. This view is shared by the Western critic Samuel who described what he saw as the relationship between the theatre and politics in these words: "theatre, as the most public of arts, is second cousin to politics, and even when the relationship is a forbidden one, there is a two-way traffic between them” (Samuel, MacColl, \& Cosgrove, 1958, p. xiii). This idea of "politicisation" is described by Wannus as intellectual, but also sees it as having a second angle, the artistic. He wanted his theatre to be avant-garde in its attempt to address a certain stratum in society. Theses are the populace or working class, whose political awareness had been stunted, whose artistic taste had been corrupted, and whose popular culture had been distorted in authoritarian works, which ruined and stifled the development of their literary appreciation (Wannus, 1970, p. 109). These classes were the victims of constant pressure from the authorities in order to keep them ignorant and un-politicized, because it was they who might turn one day bring about revolution and change. Therefore, the theatre had to seek new and innovative means of communicating with them.

Like the innovative German playwright Bertold Brecht, Wannus regarded his plays as social experiments, requiring detachment, not passion from the audience. He rejected the traditional make-believe of the theatre in favour of seeing the stage as a stage, the actors as real people and the audience as an integral and very important part of the performance. He had turned his back on the old Western theatre, as described in the words of Piscator (1963): 'the plain man saw the theatre as a 'temple of the muses', to be entered in white tie and tails and in a mood of appropriate elation” (p. 30). Fortunately, that perception had never been current in the Arab world. 


\section{Purpose of This Theatre}

The main aim of the theatre of politicisation was to change and develop a mentality and strengthen a collective consciousness in an Arab historical context (Wannus, 1988, p. 26). To achieve this aim, or the right form for the theatre, Wannus relied on experimenting until the right form was found, that would lead to a dialogue, through which an effective popular theatre linked to the people would emerge. The theatre has no ready-made form, but was a continuous process of work and experiment (Wannus, 1988, p. 113).

The theatre of politicisation required the actors to be aware of the theatre's political role, to know that the conflict in drama is a social one, and to realise that they all had a share in their commitment to a political and historical cause. As for the audience, the theatre of politicisation required them, firstly, to realize their own importance, because everything on stage is targeted and addressed to them. Secondly, they had to abandon their passivity and try to take a stand on what they saw and head on stage. Thirdly, they had to take responsibility, because their stand would have important and dangerous consequences for the country as well as themselves. The audience, therefore, had to change its attitude towards the theatre, reject being used or deceived, and be ready to intervene in the dialogue. They had to stop an action that was designed to anaesthetise them, they had to scream, and even stop the performance if they found truth being distorted (Wannus, 1988, p. 43).

The audience's response to theatre of politicization was to be related to the issues presented to them on stage and not to particular characters. Wannus (1977) analysed this view by saying: "in this play, Haflat Samar, there are no characters in the traditional meaning of the word. They are voices and features of a certain composition and do not possess any particular dimensions. Their characteristics are conceived according to what they add in lines or details to the image of the general historical composition” (pp. 3-41). There was neither individual hero nor a protagonist in the plays of Wannus but collective heroism, exactly like the characters in the epic theatre of Brecht, in Piscator's political theatre, and in Peter Weiss's documentary theatre, where the characters are symbols of class and intellectual positions and commitments rather than individuals (Isma'il, 1981, p. 115).

Like the political theatre of Piscator, Wannus' theatre of politicisation does not depend on dramatic progress, but rather on an accumulation of episodes. This has led Piscator to "break the absoluteness of the dramatic form and establish a narrative theatre” (Zondi, 1977, p. 126). Wannus adopted this method in his theatre of politicisation by employing the narrative form of the Hakawati (story teller) of the Arabian Nights (1706) or the traditional Arab café in order to break the dramatic illusion and use that character as a medium between the stage and the audience.

Wannus was influenced by Brecht's epic theatre and Weiss's documentary theatre when he dealt with political issues that carry a universal human theme not connected to a specific place or time, such as issues of freedom, authoritarian regimes, and the relationship between the ruler and the ruled (Isma'li, 1981, p. 125). Like Brecht, Weiss, and Piscator, Wannus believed that "the theatre can effect change in society, by influencing the lives of many people, as the Greek theatre did, through the truthful imitation of reality” (Bentley, 1975, p. 462).

\section{Wannus and Later Works}

In the Arab world, where authoritarian regimes have long flourished, rulers have demanded that art remains neutral towards public affairs. Wannus (1992) commented: "Every political system tries to select the culture that supports it... and to discharge art from any role in change” (pp. 54-55). He believed that artistic, social economic, 
and political concepts were shaped by history. In Arab countries they had evolved under the hegemony of a bourgeois culture which had dominated the region from the late 19th century. Later technological progress had made the bourgeoisie still more powerful, especially in the countries under Western colonization or power. Wannus saw his goal to break this mould and build a reconstructed theatre. His play Haflat Samar (1977), written in Paris in 1968, has been seen as the most important dramatical work dealing with the 1967 defeat. The play is in effect a trial of regimes, ideas, and leaders. Wannus is the public prosecutor and the audience are both judge and jury. This is a play, like those of Peter Weiss, which is a documentary, addressing the issue of defeat and inviting the audience to an instant exchange of opinions.

In his later works, al-Fil Ya Malik al-Zaman (The Elephant O, King of All Ages, 1969), Mughamarat Ra's al-Mamluk Jabir (The Adventure of the Slave Jabir's Head, 1970), Sahra Ma'a Abu Khalil al-Qabbani (An Evening With Abu Khalil al-Qabbani, 1972), and al-Malik Huwa al-Malik (The King Is the King, 1997), Wannus adopted from Brecht the technique of "the parable". Through stories taken from the Arab cultural heritage, the audience contemplate a parable they know. They are not surprised by its events, which are already familiar, but are invited to look at its meaning in depth. In such plays, Wannus examined from a Marxist and socialist perspective the relationship between authority, embodied in a king, Caliph, Vizier or president, and the people. The theatre was to become a way to knowledge, awakening the taste of the audience and criticizing the aesthetic values of current art and the media (Wannus, 1988, p. 136). The theatre of politicisation was to be a gradual process aiming at stimulating the intellect of the audience. It focuses on the issue of hukm (government) and presents for the audience's consideration people who are directly subject to it.

\section{Conclusions}

It is true that some political elements appeared before 1967 in Arab drama in the plays of Ya'qub Sanu, Ahmad Khalil al-Qabbani, Mahmoud Taimur, Nu'man Ashur, and others. But the real emergence of political theatre in the Arab world came after the 1967 defeat, in the work of Sa'd Allah Wannus. Deeply being affected by the defeat, and influenced by the 1968 upheavals in the streets of Europe, especially Paris, Wannus committed himself to starting and continuing a process of politicizing the people through experimentation in a new theatre, seeking to insight and bring about ideological and social change in the Arab world. This process of insighting the audience into action against the regimes and expanding the theatre to become a tool for revolution and change, is the essence of the theatre of politicisation.

\section{References}

Al-'Ishari, A. (1985). al-Masrahiyya al-Siyasiyya fi al Watan al-'Arabi (The political play in the Arab world). Cairo: Dar al-Ma’arif.

Bentley, E. (1975). Theory of modern theatre (Y. 'Abd al-Masih, Trans.). Baghdad: Ministry of Culture.

Isma'il, F. (1981). al-Kalima. Al Fi'l fi Masrah Sa'd Allah Wannus (The word, The deed in the theatre of Sa'd Allah Wannus). Beirut: Dar al-Adab.

Piscator, E. (1963). The political theatre (H. Rorrison, Trans.). London: Eyre Methuin.

Ramadn, K. (1984). Masrah Sa'd Allah Wannus (The Theatre of Sa'ad Allah Wannus). Kuwait: Al-Manaber Publishing.

Samuel, R., MacColl, E., \& Cosgrove, S. (1958). Theatres of the left 1880-1935 (p.xiii). Routledge: Kegan Paul, London.

Wannus, S. (1970). Bayanat Li-Masrah 'Arabi Jadid (Statements for A New Arab Theatre). al Ma'rifa (The knowledge) (pp. 17-23). Damascus: Ministry of Culture.

Wannus, S. (1977). Haflat samar. Beirut: Dar Al-Adab. 
Wannus, S. (1987). Mughamarat Ra's al-Mamluk Jabir (The Adventure of the Head of the Slave Jaber). Beirut: Dar Al-Adab. Wannus, S. (1992). Hawamish Thaqafiyya (Statements for a New Arab Theatre). Beirut: Dar al-Adab.

Wannus, S. (1988). Bayanat li-Masrah 'Arabi Jadid (Statements for A New Arab Theatre). Beirut: Dar al-Fikr al-Jadid. Zondi, P. (1977). Theory of modern drama (A. Haydar, Trans.). Damascus: Ministry of Culture. 